\title{
Continuing Revelation and Institutionalization: Joseph Smith, Ralph Waldo Emerson and Charismatic Leadership in Antebellum America
}

\author{
Claudia Jetter* \\ Ruprecht-Karls Universität, Heidelberg
}

\begin{abstract}
Nineteenth-century North American religious history is filled with divinely inspired people who received and recorded new revelations. This article presents Joseph Smith Jr and Ralph Waldo Emerson as charismatic prophets who promoted the idea of continuing revelation. Drawing on Max Weber's concept of charismatic authority, it will contrast their forms of new sacred writing with one another to show how both had experienced encounters with the divine. The second part will then explore how different conceptualizations of revelation led to opposing concepts of religious authority, with consequences for the possibility of institution-building processes. While Smith would reify revelation in hierarchy, Emerson eventually promoted extreme spiritual individualization by rejecting the idea of an exclusive institution as the centre of revelatory authority.
\end{abstract}

On 22 March 1839, while being held at Liberty Jail in Clay County, Missouri, Joseph Smith Jr (1805-44), founder of the Mormon church, dictated a response letter to Isaac Galland, a non-Mormon land broker from Iowa ${ }^{-1}$ In the letter, Smith elucidated the core belief of the Mormon faith:

* Heidelberg Center for American Studies (HCA), Curt und Heidemarie Engelhorn Palais, Hauptstraße 120, D-69117 Heidelberg, Germany. E-mail: cjetter@hca.uni-heidelberg.de.

${ }^{1}$ Joseph Smith Jr founded the Church of Jesus Christ of Latter-Day Saints in 1830 . He translated the Book of Mormon and was prophet and the highest member of the church for the rest of his life. He was assassinated in 1844 by a violent mob while imprisoned in Carthage, Illinois. For an in-depth biography of Smith, see Richard L. Bushman, Joseph Smith: Rough Stone Rolling (New York, 2007).

Studies in Church History 57 (2021), 233-253 (C) The Author(s), 2021. Published by Cambridge University Press on behalf of Ecclesiastical History Society. This is an Open Access article, distributed under the terms of the Creative Commons Attribution-NonCommercial-ShareAlike licence (http://creativecommons.org/licenses/by-nc-sa/4.0/), which permits non-commercial re-use, distribution, and reproduction in any medium, provided the same Creative Commons licence is included and the original work is properly cited. The written permission of Cambridge University Press must be obtained for commercial re-use.

doi: $10.1017 /$ stc. 2021.12 
... the first and fundamental principle of our holy religion is that we believe that we have a right to embrace all, and every item of truth, without limitation or without being circumscribed or prohibited by the creeds or superstitious notions of men, or by the dominations $[s i c]$ of one another, when that truth is clearly demonstrated to our minds, and we have the highest degree of evidence of the same ... We believe that we have a right to revelations, visions, and dreams from God, our heavenly Father. ${ }^{2}$

In this short paragraph, it becomes evident what distinguished the Mormon faith from most contemporary religious movements: belief in an ever-communicating and self-revealing deity. For Smith and his followers, dreams and visions had not been confined to the apostolic age but were actual manifestations of divine truth in the present and therefore superior to human knowledge, traditional practices and ecclesiastical creeds. God was still communicating his will, and his divine orders needed to be defended and followed even in the face of severe opposition.

Only eight months earlier, on 15 July 1838, in Cambridge, Massachusetts, the former Unitarian minister Ralph Waldo Emerson (1803-82) had given his radical critique of historical Christianity, the infamous 'Divinity School Address', in front of the Unitarian elite. ${ }^{3}$ He lamented: 'The stationariness of religion; the assumption that the age of inspiration is past, that the Bible is closed ... indicate with sufficient clearness the falsehood of our theology. It is the office of a true teacher to show us that God is, not was; that He speaketh, not spake. ${ }^{4}$

At first glance, these two men seemed to have shared the same belief, namely that God was still communicating with people, and that people had simply turned away from their immediate relation

2 Joseph Smith Jr, 'To Isaac Galland: 22 March 1839', in The Personal Writings of Joseph Smith, rev. edn (Salt Lake City, UT, 2002), 454-62, at 458-9.

3 Ralph Waldo Emerson was a Unitarian minister before becoming an influential essayist, lecturer and philosopher. Today he is canonized in American literature as one of the major writers of the American Renaissance and dubbed the 'Sage of Concord'. For a comprehensive biography, see Robert D. Richardson, Emerson: The Mind on Fire: A Biography (Berkeley, CA, 1996).

${ }^{4}$ Ralph W. Emerson, 'An Address: Delivered before the Senior Class in Divinity College, Cambridge, Sunday Evening, 15 July, 1838', in Ralph W. Emerson, The Collected Works of Ralph Waldo Emerson, 1: Nature, Addresses and Lectures, ed. Alfred R. Ferguson (Cambridge, MA, 1971), 76-93, at 89. 
to him, had stopped listening to divine truth and had turned towards hollow creeds that rejected new revelation as heretical. Yet Emerson would have regarded any self-declared prophet with suspicion, especially if that prophet demanded exclusive authority over others, warning his readers: "Beware of the man who says, "I am on the eve of a revelation." 5 Emerson's suspicion was grounded in the belief that revelation was not tied to a divine mission and channelled through one chosen vessel but a continuing process of nature revealing itself to humanity, through which every individual could experience the divine. $^{6}$

It cannot be denied, however, that both men rejected a supposedly corrupted Christianity in favour of belief in continuing revelation as the only true source of religious authority. ${ }^{7}$ While their records of divine revelation seem different, they are structurally related attempts to restore what sociologist Max Weber called charismatic authority. Although the two men were separated by deep differences in social and cultural position, they responded similarly to a perceived crisis of religious authority in a competitive religious sphere that followed an intense period of revivalism and the disestablishment of churches after the Revolution. For Smith, a poorly educated farmer from the 'burned-over district' of New York state, as well as for Emerson, the Harvard-trained genteel Bostonian, locating religious authority in immediate communication with the divine emerged as a possible alternative to traditional carriers of authority in a highly fragmented religious realm. Smith and Emerson were not the only people who hungered for new revelation. Rather, they had been part of a broader

5 Ralph W. Emerson, The Collected Works of Ralph Waldo Emerson, 6: The Conduct of Life, ed. Barbara L. Packer, Joseph Slater and Douglas E. Wilson (Cambridge, MA, 2003), 70-1.

6 Emerson's concept of 'Nature' would correspond with a naturalized and spiritualized form of God who pervaded nature and history. He would also give this concept labels such as 'Supreme Being' and 'Over-Soul'. Emerson believed the Divine Spirit would reveal itself through Nature, which he would define as 'all that is separate from us, all which Philosophy distinguishes as the NOT ME, that is, both nature, and art, all other men and my own body': Emerson, 'Nature', in Collected Works 1, ed. Ferguson, 7-45, at 8.

7 I follow sociologist Rodney Stark's definition of supernatural communication as an individual's 'capacity to perceive revelations, whether this be an openness or sensitivity to real communications or consists of unusual creativity enabling them to create profound revelations and then to externalize the source of this new culture': Rodney Stark, 'A Theory of Revelations', Journal for the Scientific Study of Religion 38 (1999), 287-308, at 295. 
public discourse that would embrace divine communication and the production of new sacred writings as a way to restore true religion. ${ }^{8}$ Although Smith and Emerson were born only two years apart, and extensive scholarship exists on both, scholars have usually regarded them as iconic figures from completely different worlds. While literary scholars concentrate on Emerson when investigating themes such as prophetic authority or revelation, the same themes in Smith's life and work have tended to be reserved for religious historians and sociologists. ${ }^{9}$ Only a handful of studies discuss Smith and Emerson as contemporaries. Two major studies stand out here. One is David Holland's Sacred Borders, in which Smith and Emerson figure among a variety of people who challenged scriptural authority with new sacred writing. The other is Paul Conkin's American Varieties, which presents both as part of a larger discourse community acting out of a restorationist impulse to recover an uncorrupted Christianity. ${ }^{10}$ Apart from a few articles that explicitly compare the two as scholars, typical examples of Romanticism or advocates of

${ }^{8}$ I use the term 'new sacred writing' for a broad range of recorded divine experiences and inspirations. This includes Joseph Smith's translation of the Book of Mormon, and his recorded visions and inspired translations, as much as Ralph Waldo Emerson's poetic descriptions of his visionary encounters with the divine. David F. Holland argues that Shakers, Mormons and Adventists grappled with the canonical boundaries of the Christian Scriptures just as much as Deists, Hicksite Quakers or others, 'and in that sense they rightly belong to the same community of discourse': Sacred Borders: Continuing Revelation and Canonical Restraint in Early America (New York, 2011), 10.

9 For Smith and revelation, see Terryl Givens, By the Hand of Mormon: The American Scripture that Launched a New World Religion (New York, 2002). On Smith and prophetic charisma, see Lawrence Foster, 'The Psychology of Prophetic Charisma: New Approaches to understanding Joseph Smith and the Development of Charismatic Leadership', Dialogue: A Journal of Mormon Thought 36/4 (2003), 1-14. For Smith's beginnings as a visionary, see Richard Lyman Bushman, Joseph Smith and the Beginnings of Mormonism (Urbana, IL, 1984). On Emerson and revelation, see Alan D. Hodder, Emerson's Rhetoric of Revelation: Nature, the Reader, and the Apocalypse within (University Park, PA, 1989); Evelyn Barish, Emerson: The Roots of Prophecy (Princeton, NJ, 1989). On Emerson's use of biblical imagery, see B. L. Packer, Emerson's Fall: $A$ New Interpretation of the Major Essays (New York, NY, 1982). For Emerson as a secular prophet, see David Robinson, Apostle of Culture: Emerson as Preacher and Lecturer (Philadelphia, PA, 1982). On Transcendentalism and Romantic scripture-writing, see Lawrence Buell, New England Literary Culture: From Revolution through Renaissance (repr. Cambridge, MA, 1993).

10 See Holland, Sacred Borders; Paul Keith Conkin, American Originals: Homemade Varieties of Christianity (Chapel Hill, NC, 1997); Catherine L. Albanese, A Republic of Mind and Spirit: A Cultural History of American Metaphysical Religion (New Haven, CT, 2008). 
autonomy, only the historian Richard Brodhead discusses them as prophets, but without regard to institution-building. ${ }^{11}$ This article therefore examines them specifically as inspired leaders and investigates their shared openness to new divine communication, while differentiating their concepts of legitimate religious authority.

Drawing on Max Weber's concept of charisma, this article considers Joseph Smith Jr and Ralph Waldo Emerson as charismatic prophets who contested existing ecclesiastical institutions with their belief in continuing revelation, offering such a perspective to more general scholarly discussion on religious authority and agency in midnineteenth-century America. While many historians, including Nathan Hatch in his seminal study The Democratization of American Christianity (1989), have framed the erosion of traditional forms of religious authority, the rise of populist religious leaders and the rapid pluralization of the American religious landscape as a process of liberation that added to a more general growth of democratic culture, a number of recent studies have emphasized the widely felt anxiety of many Americans amidst the upheavals of the Second Great Awakening that followed the disestablishment of the churches. ${ }^{12} \mathrm{By}$ applying the concept of charisma to these two historical examples, the article provides deeper insights into different forms of leadership and institutionalization processes in the historical context of antebellum America, thereby demonstrating how historians can benefit from the deployment of such theories. The theoretical background regarding charismatic authority will help uncover shared commonalities among Smith and Emerson, who are usually seen as contemporaries from culturally opposing worlds, without obscuring their crucial differences. This article argues that both Smith and Emerson advocated

\footnotetext{
11 Richard H. Brodhead, 'Prophets in America circa 1830: Ralph Waldo Emerson, Nat Turner, Joseph Smith', in Reid L. Neilson and Terryl L. Givens, eds, Joseph Smith, Jr: Reappraisals after Two Centuries (Oxford, 2009), 13-31. For other themes, see Evan Carton, 'American Scholars: Ralph Waldo Emerson, Joseph Smith, John Brown, and the Springs of Intellectual Schism', New England Quarterly 85 (2012), 5-37; Benjamin Park, "Build therefore, your own world": Ralph Waldo Emerson, Joseph Smith, and American Antebellum Thought', Journal of Mormon History 36 (2010), 41-72; Ryan W. Davis, 'Frontier Kantianism: Autonomy and Authority in Ralph Waldo Emerson and Joseph Smith', Journal of Religious Ethics 46 (2018), 332-59.

12 See James D. Bratt, 'Religious Anti-Revivalism in Antebellum America', Journal of the Early Republic 24 (2004), 65-106; Amanda Porterfield, Conceived in Doubt (Chicago, IL, 2012). For Hatch's democratization thesis, see Nathan O. Hatch, The Democratization of American Christianity (New Haven, CT, 1989).
} 
continuing revelation and developed charisma based on visionary experiences. By contrasting their different forms of new sacred writing, it demonstrates how they began by democratizing charismatic authority through 'spiritual self-authorization' and the promotion of revelation as something available to all. ${ }^{13}$ The second part of the article will show, however, that they held differing concepts of revelation and opposing ideas on the degree to which believers were expected to submit to new divine communication. These would lead in Emerson's case to extreme spiritual individualization that precluded any form of established religion, and in Smith's case to the establishment of a fixed religious community with a canon of sacred texts and hierarchical institution-building.

\section{The Relation between Revelations, Charismatic Authority AND BELIEVERS}

First, it is necessary to establish a theoretical framework to understand why the personal spiritual distress of Smith and Emerson led them away from established religious institutions and doctrines and towards a belief in an active and communicative God who would reveal himself to them. Weber believed that charismatic authority emerged in times of political or spiritual crisis as an absolute and extraordinary form of authority that could affect the religious as well as the secular realm. He defined charisma as

... a certain quality of an individual personality by virtue of which he is set apart from ordinary men and treated as endowed with supernatural, superhuman, or at least specifically exceptional powers or qualities. These are such as are not accessible to the ordinary person, but are regarded as of divine origin or as exemplary, and on the basis of them the individual concerned is treated as a leader. ${ }^{14}$

Charismatic authority is legitimized by its extraordinariness. In regard to religious authority, charisma finds its purest expression in the

\footnotetext{
13 By 'spiritual self-authorization', I mean the turn away from mediating authorities such as ministers and denominational hierarchies towards an immediate and ultimate source of religious authority. By democratization, I mean the possibility of establishing a charismatic authority which in theory is open to everyone, to the extent of their spiritual giftedness. ${ }_{14}$ Max Weber, On Charisma and Institution Building: Selected Papers, ed. S. N. Aiznšțadț (repr. Chicago, IL, 1992), 48.
} 
prophet who establishes authority based on his claim to immediate access to an ultimate, divine source, mostly through visions and revelations. ${ }^{15}$ Weber argues that charisma, as a pure type, is disruptive as it usually entails a complete reorientation of the prevailing value system and the rejection of all forms of traditional authority. This exceptionality, however, is difficult to maintain for long. Therefore Weber believed charisma necessarily transformed itself into a more sustainable form of authority over time. Weber called this 'a routinization of charisma': the integration of charisma into everyday life to make it practicable. ${ }^{16}$ Over time, charisma would transform into traditional authority, with established rituals that would help to legitimize the transfer of authority to another person or group, or even an office. The process of routinization, however, only becomes relevant once a coherent group is formed in which the leader wishes to maintain a leadership position.

Although various aspects have been criticized throughout the twentieth century, many sociologists made use of, and further developed, Weber's category, which was also transformed in the late twentieth century into a popularized form of mystical appeal on the part of influential public figures. ${ }^{17}$ These figures were for Weber exclusively male: his failure to acknowledge and include female charismatic leaders has figured amongst the most prominent points of critique in recent years. ${ }^{18}$ Among sociologists who looked into a broader conceptualization of charisma was Edward Shils, who critiqued 'the "segregation" of charisma in the course of institutional establishment through its concentration into specific action, roles, or occasions, while it evaporated from the rest of the system', ${ }^{19}$ and argued for the possibility of charisma existing in a dispersed or more attenuated form in secular institutions where it would function as a disruptive force but could also maintain social order. $^{20}$ Challenging Weber's leader-centredness, Charles

15 Ibid. 51-2.

16 Ibid. 54.

17 For the trajectory of the word 'charisma', from its Pauline conception through Weber's re-invention to its appropriation by twentieth-century media, see John Potts, A History of Charisma (Basingstoke, 2009).

18 On the trajectory of the charisma and gender discussion and why the concept still carries value if critically applied, see Paul Joosse and Robin Willey, 'Gender and Charismatic Power', Theory and Society 49 (2020), 533-61.

19 Edward Shils, 'Charisma, Order, and Status', American Sociological Review 30 (1965), 199-213, at 202.

${ }^{20}$ Ibid. 200. 
Camic investigated the preconditions for charisma and their implications for different phenomena associated with it. Highlighting followers' 'differing extraordinary needs' which need to be fulfilled by a prophet, Camic emphasized the agency of the disciples 'who impute the specialness' to the charismatic figure. ${ }^{21}$ Sociologists in the $1990 \mathrm{~s}$ then continued this trajectory of charisma as a dynamic and nonessential category which is ascribed to somebody, with Rodney Stark pointing out the reciprocal ascription processes between a charismatic figure and 'holy families', that is, a prophet's earliest and closest disciples, ${ }^{22}$ in what sociologist Paul Joosse has most recently called 'the charismatic aristocracy'. ${ }^{23}$ Scholars from other fields have also drawn attention to a set of character traits apparently shared among many charismatic leaders. ${ }^{24}$

Weber believed 'charismatic inspiration' 25 to be the foundation of authority but he was generally more interested in its legitimizing function than in the actual nature of the inspiration. Whether a prophet was truly inspired or a fraud did not matter to Weber as long as people recognized a prophet's inspiration as authentic and thus followed him (or his example). Thus, Weber's list of 'classical' examples of charismatic figures would not only include religious prophets with visions or Native American shamans, but also secular figures such as war heroes or demagogues. In a specific treatment of prophets in his Sociology of Religion (1920), however, Weber focused on the religious charismatic figure, thereby highlighting prophets who transmit revealed knowledge and distinguishing them from gurus with acquired knowledge or reformers who lack 'that vital emotional preaching which is distinctive of prophecy, regardless of whether this is disseminated by the spoken word, the pamphlet, or any other type

21 Charles Camic, 'Charisma: Its Varieties, Preconditions, and Consequences', Sociological Inquiry 50 (1980), 5-23, at 16.

22 Stark, 'Theory of Revelations', 305.

23 Paul Joosse, 'Max Weber's Disciples: Theorizing the Charismatic Aristocracy', Sociological Theory 35 (2017), 334-58, at 337.

${ }^{24}$ Religious studies scholar Catherine Wessinger suggests energetic leadership, exemplary behaviour and willingness to personal sacrifice are among them: 'Charismatic Leaders in New Religions', in Olav Hammer and Mikael Rothstein, eds, The Cambridge Companion to New Religious Movements (Cambridge, 2012), 80-96, at 90-1. Psychologist Len Oakes sees narcissism as the defining trait of charismatic leaders: Prophetic Charisma: The Psychology of Revolutionary Religious Personalities (Syracuse, NY, 2011).

25 Weber, On Charisma and Institution Building, 51-2. 
of literary composition'. ${ }^{26}$ What Weber described as the 'vital emotional preaching' is the key aspect when it comes to the dynamic relation between prophet and disciple. On the one hand, there is the prophet who feels called to communicate spiritual experience through preaching or writing; on the other hand, a receptive audience who believe in the prophet's ability to access 'an unseen source of authority' 27 is just as essential. Charisma is thus ascribed to a prophet and effectively co-created by both prophet and believers. ${ }^{28}$

While it could be argued that adopting a concept from the twentieth century and applying it to nineteenth-century figures may risk de-historicizing them, it should also be noted that there are inherent as well as historical connections between Weber's concept of charisma and these prophets that justify the application of the concept. In a footnote, Weber himself mentions Smith as a recent example of a charismatic prophet of the modern world. ${ }^{29}$ With this example in mind, it is not surprising that Smith as a prophet is in perfect accordance with Weber's subcategory of the 'ethical prophet'. This kind of prophet serves as 'an instrument for the proclamation of a god and his will, be this a concrete command or an abstract norm. Preaching as one who has received a commission from God, he demands obedience as an ethical duty'. ${ }^{30}$ Yet there are less obvious examples of charismatic prophets, including Emerson. Although Emerson rejected religious institutions and discouraged discipleship, he nevertheless enchanted his audience in lectures, addresses and essays with his poetically framed experiences of the divine, inviting them to follow his path to spiritual self-reliance. While this does not resemble the 'ethical prophet', Emerson often praised history's exceptionally gifted

26 Ibid. 261. Charles Camic discusses the problem of discontinuity in Weber's charisma concept. He believes Weber's increasing focus on the dualism of charisma and institution to be responsible for the subtle changes: 'Charisma', 8.

27 Wessinger, 'Charismatic Leaders', 80-1.

28 Oakes suggests that followers are not simply swept away but follow because it helps their own 'spiritual quest': Prophetic Charisma, 126-7. He thus follows Benton Johnson's approach to charismatic leadership with his focus on personal and relational factors that characterize charismatic leadership: see Benton Johnson, 'On Founders and Followers: Some Factors in the Development of New Religious Movements', Sociological Analysis 53 (1992), 1-13; cf. Weber, On Charisma and Institution Building, 254.

29 Max Weber et al., eds, Wirtschaft und Gesellschaft. Soziologie. Unvollendet 1919-1920, Gesamtausgabe Schriften und Reden 23 (Tübingen, 2013), 491-2.

30 Weber, On Charisma and Institution Building, 263. 
men and in his writings of the late 1830s he regularly assumed a pseudo-prophetic persona that strongly resembled the figure of the inspired genius. The same Romantic discourse that informed Emerson's idea of the 'holy bard', and thus his own performance, similarly informed Weber's category of charismatic authority, and more specifically his sub-category of the 'exemplary man', whose preaching 'says nothing about a divine mission or an ethical duty of obedience, but rather directs itself to the self-interest of those who crave salvation, recommending to them the same path as he himself traversed'. ${ }^{31}$ These two different types of charismatic prophets and their notions of inspiration and authority play a decisive role in determining the possibility of the community of followers taking institutional shape.

\section{RECEIVING ReVELATIONS}

Although he was a young, uneducated farmer, Joseph Smith assumed the powerful leadership position in one of the fastest growing new religious movements of the 1840 s, based simply on his claims to be God's chosen mouthpiece. Like Emerson, Smith believed that the heavens had not been closed; God was still willing to reveal himself to his people. According to his personal account, Smith had been unable to settle with any congregation, as the revivalist spirit of most congregations had soon dissolved into sectarian strife and competition:

[It] was seen that the seemingly good feelings of both the Priests and the Converts were more pretended than real, for a scene of great confusion and bad feeling ensued; Priest contending against priest, and convert against convert so that all their good feelings one for another (if they ever had any) were entirely lost in a strife of words and a contest about opinions. ${ }^{32}$

Frustrated by this corruption of pure religious enthusiasm, Smith reports how he randomly opened the Bible at James 1: 5: 'If any of

\footnotetext{
31 Ibid. Several sociologists have pointed out the similarities between Weber's concept of the charismatic leader and the Romantic concept of the artistic genius, as presented in Thomas Carlyle's On Heroes: see Hans H. Gerth and C. W. Mills, 'Introduction', in eidem, eds, From Max Weber: Essays in Sociology (New York, 1958), 3-76, at 53. John Potts also suggests a similarity between Weber's charismatic leader and Nietzsche's 'Übermensch', a concept partially inspired by Emerson, as Nietzsche himself was an avid Emerson reader: History of Charisma, 112.

32 Joseph Smith Jr, 'History (1838)', in Personal Writings, 226-40, at 228-9.
} 
you lack wisdom, let him ask of God, that giveth to all men liberally, and upbraideth not; and it shall be given him', and took these words to heart. He circumvented ministerial guidance and turned to God instead to find out which church to join. In his 1838 account he remembered the vision of 1820 as follows:

After I had retired into the place where I had previously designed to go, having looked around me and finding myself alone, I kneeled down and began to offer up the desires of my heart to God, ... I saw a pillar of light exactly over my head above the brightness of the sun, which descended gradually untill $[s i c]$ it fell upon me. When the light rested upon me I saw two personages (whose brightness and glory defy all description) standing above me in the air. One of them spake unto me calling me by my name and said (pointing to the other) 'This is my beloved Son, Hear him.' My object in going to enquire of the Lord was to know which of all the sects was right, that I might know which to join. ... I was answered that I must join none of them, for they were all wrong, and the Personage who addressed me said that all their creeds were an abomination in his sight ... ${ }^{33}$

Although this vision did not yet include a specific mission, it is still striking that, for Smith, communicating with God did not seem extraordinary. He was surprised by the intensity of the visitation by God and Jesus Christ, but he never doubted the reality of the vision. The content was special, not the communication itself. Smith's visions and the visionary encounters of people within the Book of Mormon were not 'shadowy spiritual intimations'34 but what Terryl Givens calls 'Dialogic Revelation'. ${ }^{35}$ Smith accepted revelation as a supernatural event and as the appropriate way in which God would communicate with people. Revelation had become an act of spiritual self-authorization, a practice that was available to all, regardless of their social position. By randomly opening his Bible at James 1: 5 and following God's word instead of a minister's advice, the farmer Smith had developed spiritual authority. In this initial moment of the movement, Smith democratized revelation.

By the time Emerson gave his rebellious 'Divinity School Address', he had already left the Unitarian ministry, had become a member of

33 Ibid. 230-1.

34 Givens, By the Hand of Mormon, 219.

35 Ibid. 218. 
the notorious Transcendentalists, and had begun to establish his second career as a lecturer and writer. ${ }^{36}$ By leaving behind the ministerial office, he was able to overcome his spiritual crisis caused by a church which he diagnosed as marked by empty formalism and second-hand inspiration. It was obvious to him that tradition and institutionalization had slowly killed religious sentiment. He thus proposed to the young graduates, many of whom were about to enter the ministry, that they should become 'newborn Bards of the Holy Spirit', ${ }^{37}$ and reveal their own experience of divine truth to their future congregations.

Emerson did not wait until he had left the ministry to begin developing his concept of an eternally revealing divine spirit. Indeed, the first traces of his spiritualized idea of present-day prophecy, in the form of preaching and writing, could already be found in his sermons of the early 1830s. ${ }^{38}$ Even as a minister at Boston's Second Church, Emerson had occasionally warned against restricting divine inspiration: 'do not confine it to one season or one gift. ... $[A] l l$ is spiritual influence, and its omnipresence excludes every superstitious distinction.' ${ }^{39}$ In the first sermon after ordination in 1829, he blamed Christianity's corruption on Christians being 'much addicted to a few words' and holding on 'to phrases when the lapse of time has changed their meaning, ${ }^{40}$ Restricting religious sentiment to one

36 The 'Transcendentalists' were a network of progressive writers, reformers and (former) Unitarian ministers who actively shaped and influenced antebellum intellectual life. Among their most prominent members were social activists and writers, including Margaret Fuller, Theodore Parker and Henry David Thoreau. For a helpful introduction to Transcendentalism and its roots, see Barbara L. Packer, The Transcendentalists (Athens, GA, 2007).

37 Emerson, 'An Address', in Nature, Addresses and Lectures, 90.

38 My analysis of Emerson's concept of revelation is based on selected sermons and his early post-ministerial writing, thus focusing on the period 1830-41. During this time, he was preoccupied with themes that are relevant for the discussion here, including questions of moral self-culture, revelation through history and nature, and the relation between the divine soul and man. After 1841, there is a perceptible decline in Emerson's Romantic millennial enthusiasm and in the attention given to divine revelation, while ethical considerations expressed in social and political activism become more central to his thought amid rising tensions about slavery in the United States.

39 Ralph W. Emerson, Sermon 110, in The Complete Sermons of Ralph Waldo Emerson, vol. 3, ed. Albert J. von Frank (Columbia, MO, 1991), 118-25, at 124 (emphasis mine). Emerson preached this sermon five times between 1831 and 1837 .

40 Ralph W. Emerson, Sermon 28, in Complete Sermons, vol. 1, ed. Albert J. von Frank (Columbia, MO, 1989), 231-7, at 234-5. 
completed text was wrong when God would continue to reveal himself. Therefore, Emerson affirmed: 'If to me were given that starlike vision which could see and make report how they all bear evidence to it, I cheerfully would. ... It would be silly to shut myself voluntarily within a yet narrower circle, and only use a part of my pittance of truth.' ${ }^{41}$ The egalitarian tendency of receiving divine knowledge is already visible in this passage, but what Hodder called the 'democratization of the sacred' 42 becomes even more apparent when Emerson proclaimed explicitly two years later: 'Probably all men have the same capacity of prophecy and miracle. What is prophecy but more knowledge? What is miracle but more dominion of the soul over matter than is now evinced?' 43 This egalitarian tendency, however, needs to be regarded critically. Although Emerson did not explicitly exclude women or men with an ethnic minority background, his lists of ideal historical examples of inspired leaders were made up almost exclusively of white men. ${ }^{44}$

Like Smith, Emerson believed that humankind had separated itself from an ever-revealing God. People had stopped listening to their own soul, through which they could connect to the divine, and had turned towards worldly distractions, empty ritual and doctrines instead: 'The reason why the world lacks unity, and lies broken and in heaps, is, because man is disunited with himself.' ${ }^{45}$ A distorted perception of nature had misled mankind to a distorted concept of religion. For Emerson, Jesus had been one of the few examples of exceptionally inspired prophet-poets. But most people had mistaken him for an ultimate authority and had become obsessed with the biographical Jesus, while what had been truly divine about Jesus his immediate relation to God - had been forgotten. ${ }^{46}$

For Emerson, it was incomprehensible that people believed divine inspiration to have ended. He felt 'that the need was never greater

41 Ibid. 235.

42 Hodder, Emerson's Rhetoric of Revelation, 10-11.

43 Emerson, Sermon 110, 122.

44 One exception is the occasional remark about the exceptional religiosity of his aunt Mary or the inspired writing of the French mystic Jeanne Guyon. These occurred primarily in his personal writings. See, for example, Ralph W. Emerson, The Journals and Miscellaneous Notebooks of Ralph Waldo Emerson, 5: 1835-1838, ed. Merton M. Sealts (Cambridge, MA, 1965), 5, 323-4.

45 Emerson, 'Nature', 43.

46 Cf. Emerson, 'An Address', 81. 
of new revelation than now [as] ... [t] he Church seems to totter to its fall, almost all life extinct'. ${ }^{47} \mathrm{New}$ inspiration was needed and therefore Emerson asked rebelliously: 'Why should not we also enjoy an original relation to the universe?' 48 Revelations were not commandments received by one person for others to obey, but transforming spiritual experiences that anyone could have. Prophets were exceptional because they had perfected their perception of the divine further than most ordinary people, but they were not essentially different. Therefore, Emerson asked

... whether prophecy is not a state of mind more sagacious than that of other men only as that mind is more fully surrendered to God. Every day's experience shows us the different degrees of reception of wisdom by the same mind at different times.... The prophet in an exalted state of holiness therefore sees more truth than other men, but under the same conditions. ${ }^{49}$

Rather than locating divine truth in something external that could be measured empirically or grasped rationally, people could use their imagination to access divine truth within the soul. Revelation, for Emerson, came to be an encounter with the sublime, a fusion of the Universal Mind with the individual mind..$^{50} \mathrm{He}$ believed these mystical experiences to be natural rather than supernatural. These experiences demanded an emptying out of the historical, personal self and a silencing of all the worldly noise that would constantly distract. His most cited revelation, the 'transparent eye-ball' passage, describes the dissolution of his body and the union of his mind with nature, when he becomes pure perception:

Crossing a bare common, in snow puddles, at twilight, under a clouded sky, without having in my thoughts any occurrence of special good fortune, I have enjoyed a perfect exhilaration. Almost I fear to think how glad I am. ... Standing on the bare ground, - my head bathed by the blithe air, and uplifted into infinite space, - all mean egotism vanishes. I become a transparent eye-ball. I am nothing. I see all. The currents of

47 Ibid. 84.

48 Emerson, 'Nature', 7.

49 Emerson, Sermon 110, 122-3.

50 Cf. Ralph W. Emerson, 'The Over-Soul', in The Collected Works of Ralph Waldo Emerson, 2: Essays: First Series, ed. Alfred R. Ferguson and Joseph Slater (Cambridge, MA, 1979), 159-75, at 166. 
the Universal Being circulate through me; I am part and particle of God. ${ }^{51}$

This passage was the climax of a highly individualized experience. If a person left tradition and external guidance behind, it was possible to reconnect to the divine. Rather than being the exceptional gift of only one prophet, revelation had been opened as an experience for all. Over time, Emerson developed his concept of revelation even further into a mode of perceiving the divine, which could and should be cultivated by everyone. In the end, the purpose of opening the soul for revelations was to help man to recover his divine potential. After all, 'man is a god in ruins'. 52

\section{The Consequences of Different Conceptions of Revelation for POSSIBLE INSTITUTION BUILDING}

Both Smith and Emerson believed divine inspiration to be as real and intense as it had been at Pentecost. They even shared the idea that people (albeit 'people' generally implied white men) were gifted with charisma to different degrees. Despite these shared ideas, however, one crucial difference would ultimately separate them and determine the possibility of institution building within a coherent movement of believers. For Smith, the restitution of charismatic gifts, on which the (re-)establishment of the one saving church rested, entailed a sacred hierarchy. While some of Smith's closer associates, such as his wife Emma, Oliver Cowdery or David Whitmer, occasionally received authoritative revelations themselves (mostly in the company of Smith), Smith occupied an exceptional position from the very beginning of the movement. ${ }^{53}$ He was not one visionary coexisting among many. Instead, he was the divine vessel, chosen by God and not elected by fellow believers, to preside over the new church.

\footnotetext{
51 Emerson, 'Nature', 10.

52 Ibid. 42.

53 In July 1830, Smith's wife Emma received a divine order through her husband, today recorded as Doctrine \& Covenants [hereafter: D\&C] 25. D\&C 6 and 7 were given to Smith and Oliver Cowdery, when Cowdery began recording as a scribe Smith's translation of the Book of Mormon. DeC 18 was a revelation to Smith, Cowdery and David Whitmer, given at Fayette, NY, in June 1829: see The Doctrine and Covenants of the Church of Jesus Christ of Latter-day Saints: Containing Revelations given to Joseph Smith, the Prophet with some Additions by his Successors in the Presidency of the Church (Salt Lake City, UT, 2013).
} 
As a result, revelations articulated by Smith correlate with the divine commandments of Weber's 'ethical prophet'. The doctrines Smith received were meant to lead believers into the one redeeming church. Unlike Emerson's individualized practice of spiritual seeking, Smith's concept of revelation included a God who was sending specific orders to reinstate God's only true church. Once that true church had been established, authoritative revelations were relocated within that sacred order. In the revelation given to Smith at the formation of the church, on 6 April 1830, God did not send a divine message of equality but first and foremost revealed Smith's divinely sanctioned superior position within the new institution. Smith was to be 'a seer, a translator, a prophet, an apostle of Jesus Christ, an elder of the church through the will of God the Father'. ${ }^{54}$ By divine commandment, Smith immediately occupied the highest position in order to lead humanity towards salvation although, at least theoretically, the same Spirit could speak through all members. God had sanctioned Smith's revelatory superiority and ordered all believers to 'give heed unto all his words and commandments which he shall give unto you as he receiveth them, walking in all holiness before me; For his word ye shall receive, as if from mine own mouth'. 55 Revelation was reified as a hierarchy.

Smith established his position as the charismatic leader of a new church, but his ability to do so was not based simply on the visions he had received. ${ }^{56}$ The essential foundation for the new church was his new sacred writing, the Book of Mormon. For Smith, everything related to the production of this additional Bible - including recovering and hiding the gold plates and translation instruments, translating the text, enduring persecution and ridicule by neighbours, and suffering chastisement by God when he failed - served to establish his charismatic authority because it related the production to a specific mission. To recover this text and publish it was the first step towards an ecclesiastical institution for what previously had been a visionary movement. In the early years of the movement, the Book

54 DEC 21: 1.

55 Ibid.

56 Richard Bushman has argued that Smith played down his visionary experiences in the early years of the movement: 'The Visionary World of Joseph Smith', Brigham Young University Studies 37 (1997-8), 183-204. 
of Mormon thus acted as a 'signifier', ${ }^{57}$ as Givens has argued. It became the key identification marker for the early converts and separated believers from unbelievers. Thus Smith's prophetic persona was intricately linked to this new sacred writing.

Yet successful institutionalization did not only rest on additional revelation of scripture. Instead, what we find is a dynamic interplay between new revelations and the ordering of structures on the institutional level, which helped sustain charismatic gifts as a vital source in Mormonism without threatening the survival of the church. These ordering structures often developed from further revelations and they helped secure Smith's own authority as first prophet of the church. A case in point would be the revelation, now recorded as D\&C 28, given through Smith to his close associate Cowdery in September 1830 in response to the confrontation with Hiram Page, who challenged Smith's exclusive revelatory authority when claiming to have received new revelations with the help of seer stones. ${ }^{58}$

Even before the formation of the church, Smith began to reinstate ancient priesthoods through baptismal rites that helped institutionalize the movement. Over the years, more sacred rites would be added, transforming the church into a complex system of various priesthoods and offices. But while on an organizational level Smith would distribute executive power into different offices, councils and conferences, additional divine instructions eventually transformed him into the 'Prophet, Priest \& King' of a quasi-theocracy in Nauvoo on 11 April $1844 .{ }^{59}$ By then, only high-ranking church officials could reveal divine communications with authority binding on others. Several historians have therefore argued that from 1830 onwards, when the Book of Mormon was published and the church officially organized, we can no longer speak of Mormonism as an anti-clerical, democratized movement, because Smith had already begun to implement complex

\footnotetext{
57 Givens, By the Hand of Mormon, 63-4. More recently, scholars have indicated that the Book of Mormon was more than just a signifier, as historical evidence suggests its devotional and liturgical use by early Mormon converts: Janiece Johnson, 'Becoming a People of the Books: Toward an Understanding of Early Mormon Converts and the New Word of the Lord', Journal of Book of Mormon Studies 27 (2018), 1-43.

58 See also Bushman, Joseph Smith, 119-22.

59 Ronald K. Esplin, Matthew J. Grow and Matthew C. Godfrey, The Joseph Smith Papers, 1: Administrative Records (Salt Lake City, UT, 2016), 94-5.
} 
power structures. ${ }^{60}$ Michael MacKay's proposed term 'hierarchical democracy' most fittingly describes the tension between Smith's leadership as a 'type of theological king' and an ecclesiastical system in which power was diffused among chosen church leaders. ${ }^{61}$

In Weberian terms, charisma had been routinized with the effect that it

... may be transmitted by ritual means from one bearer to another or may be created in a new person. It involves a dissociation of charisma from a particular individual, making it an objective, transferable entity. In particular, it may become the charisma of office. In this case, the belief in legitimacy is no longer directed to the individual, but to the acquired qualities and to the effectiveness of the ritual acts. ${ }^{62}$

True democratization of charisma was therefore only present in the initial moment of movement building in Mormonism when an uneducated farmer claimed to have received divine commands to restore an ancient sacred order. Once the process of church organization had begun, revelation with comprehensive authority over all believers could only come from within the ecclesiastical order, which, from the mid-1800s until 1978, was reserved for white men. ${ }^{63}$

In contrast, Emerson would have abhorred the idea of locating the gift of revelation within a new church. He asked: 'What shall we do? I confess, all attempts to project and establish a new Cultus with new rites and forms, seem to me in vain. ${ }^{64}$ For him, the mistake was to establish religion in any kind of institutional form, as all institutions would eventually restrain an individual's spiritual practice. To capture the religious sentiment within a church would always kill the divine element. To establish something as authoritative was to fix it, but the

\footnotetext{
${ }^{60}$ Among them is Kathleen Flake, arguing for a system of 'shifting status relationships' instead: 'Ordering Antinomy: An Analysis of Early Mormonism's Priestly Offices, Councils, and Kinship', Religion and American Culture 26 (2016), 139-83.

61 Michael Hubbard MacKay, Prophetic Authority: Democratic Hierarchy and the Mormon Priesthood (Urbana, IL, 2020), 2.

62 Weber, On Charisma and Institution Building, 57.

63 D\&C, Official Declaration 2 refers to 'a few black male members of the Church' being ordained to the priesthood during Smith's life, but the practice was stopped after his death. In 1978, the First Presidency and the Quorum of the Twelve Apostles received a revelation that allowed 'all worthy male members of the Church [to] be ordained to the priesthood without regard for race or color'. See Joseph Smith Jr, 'Official Declaration 2', in Doctrine and Covenants.

${ }^{64}$ Emerson, 'An Address', 92.
} 
divine Spirit could not be fixed. However divinely inspired a prophet or text may be, they could never claim exclusive possession of all sacred knowledge, as divine truth would continue to be revealed and therefore could not be fully presented in one book by one church. New revelation would appear constantly, making the whole concept of authoritative sacred writing obsolete. Only the act of recording divine communication, or, in Emerson's poetic view, the act of 'scripturalizing' could be regarded as sacred. A new scripture could never be completed. Therefore Emerson neither advocated the fixing of new divine revelation in a new Bible nor encouraged the foundation of a new 'Emersonian' church.

Still, a prophetic element remains in Emerson's writings of the 1830s. He shared his experiences of the divine with a perceptive audience through his published writing. Although he presented his experiences only as examples of a way towards spiritual truth and not as a dictation of religious practice, he nevertheless assumed a pseudo-prophetic tone at times to lament the brokenness of the human soul and seemed to encourage others to follow his example of spiritual reversal. Recalling charisma's attributive nature, a group of disciples ascribed 'post-life charisma'65 to their spiritual teacher Emerson. While some enthusiastic followers attempted to establish Emerson as a Western prophet at interreligious gatherings, the 'Poughkeepsie Seer' Andrew Jackson Davis actively tried to sacralize the wisdom of Emerson, 'one of the inspired Scripturalists of this century', ${ }^{66}$ in his 'Gospel of St Ralph'. ${ }^{67}$

Emerson, however, never explicitly declared himself to be a prophet. Instead, he pointed towards history's more spiritually gifted people, who could act as inspiring teachers to show humanity how to reconnect with the divine, and he prophesied that many more would follow. These past and future prophet-poets acted as 'liberating gods'. ${ }^{68}$ Yet the only way to divine revelation was through the

\footnotetext{
65 Wessinger, 'Charismatic Leaders', 86-7.

66 Andrew Jackson Davis, A Sacred Book Containing Old and New Gospels: Derived and Translated from the Inspirations of Original Saints (Boston, MA, 1873), 32-3, 44.

67 On F. B. Sanborn and George Malloy, the 'Emersonians' at the turn of the century, see Leigh Eric Schmidt, Restless Souls: The Making of American Spirituality, 2nd edn (Berkeley, CA, 2012) 193-200.

68 Ralph W. Emerson, 'The Poet', in The Collected Works of Ralph Waldo Emerson, 3: Essays: Second Series, ed. Joseph Slater and Alfred R. Ferguson (Cambridge, MA, 1983), 3-24, at 18-19.
} 
cultivation of the individual soul through first-hand experiences of the divine rather than subjection to past genius.

\section{Conclusion}

This article has shown how sociological theories can provide a deeper understanding of the dynamic relationship between revelation and institutionalization processes in the actual historical context of antebellum America, and thereby demonstrated how historians can benefit from the use of such theories. The concept of charismatic authority provided a theoretical background that helped to uncover both Smith and Emerson as charismatic prophets who challenged existing ecclesiastical institutions by their belief in continuing revelation. While they are usually presented as contemporaries from culturally opposed worlds, the concept of charisma highlights a shared belief in continuing revelation without blurring their fundamental differences. As the case of Emerson as the 'exemplary man' has shown, the category of charisma provides a theoretical framework that enables us to present inconspicuous prophets alongside more obvious examples. It thus invites further analysis of previously under-represented charismatic women and men alongside well-known examples, thereby demonstrating the existence of a socially and culturally diverse speech community that grappled with the idea of new revelation and reached from intellectual Boston to the uncouth frontier of nineteenth-century America.

Both Smith and Emerson effectively communicated their personal experiences with the divine and established charisma. However, it was their diverging understandings of the concept of revelation that ultimately determined whether institution-building was possible (or necessary). While Smith retained revelation as a vital element, it became reified in hierarchy as all revelation with authority for the community became tied to the highest ecclesiastical offices after the foundation of the church. Smith tied revelation to a sustainable structure that would guarantee the church's survival as a united body of believers. Thus he succeeded in balancing inspiration and institution-building by incorporating the disruptive charisma in a tight concept of ecclesiastical hierarchy.

This contrasted strongly with Emerson's individualistic concept of revelation which did not require charisma to routinize within an 
institutional form, as there was no church to speak of. While Emerson elevated some exceptionally gifted poets and prophets in history, in general charismatic authority had been relocated within every single soul. The experience of divine communication had become naturalized and internalized and was an end in itself. Revelations were the vehicles that gave short glimpses into human divine potentiality and they had become so highly individualized that they could never be binding on others. Emerson could thus be regarded as the more consistent advocate of democratized charisma, given his commitment to individual spiritual authority and revelation as a universalized act of moral self-cultivation. While Smith demanded loyal support for his radical revelation of the 'new and everlasting covenant', ${ }^{69}$ Emerson's recommendation for the future Unitarian ministers at Harvard was quite different: 'to go alone; to refuse the good models, even those most sacred in the imagination of men, and dare to love God without mediator or veil'. ${ }^{70}$

$69 \mathrm{DeC} 132$. This revelation would give rise to the controversial doctrine concerning polygamy.

70 Emerson, 'An Address', 90. 